\title{
U.PORTO
}

FACULDADE DE

Mestrado Integrado em Medicina Dentária

Dissertação de Investigação

\section{In situ evaluation of the microbial adhesion on a hard acrylic resin and on a soft liner used in removable prostheses}

\author{
Ana Sofia Monteiro Gomes
}

\section{Orientadora}

Prof. a Doutora Maria Helena Guimarães Figueiral da Silva

\section{Co-orientadora}

Prof. ${ }^{a}$ Doutora Maria Benedita Almeida Garrett de Sampaio-Maia Marques

Porto, Junho de 2013 


\title{
U.PORTO
}

FACULDADE DE

Mestrado Integrado em Medicina Dentária

Dissertação de Investigação

\section{In situ evaluation of the microbial adhesion on a hard acrylic resin and on a soft liner used in removable prostheses}

\author{
Ana Sofia Monteiro Gomes
}

\section{Orientadora}

Prof. ${ }^{\text {a }}$ Doutora Maria Helena Guimarães Figueiral da Silva

Professora Catedrática da Faculdade de Medicina Dentária da Universidade do Porto

\section{Co-orientadora}

Prof. - Doutora Maria Benedita Almeida Garrett de Sampaio-Maia Marques

Professora Auxiliar da Faculdade de Medicina Dentária da Universidade do Porto 


\section{Índice}

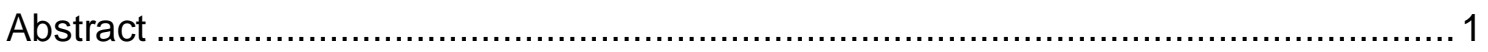

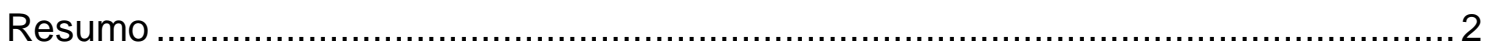

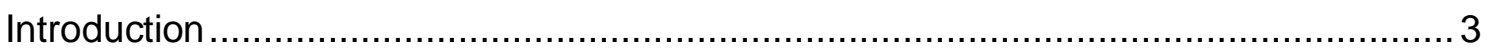

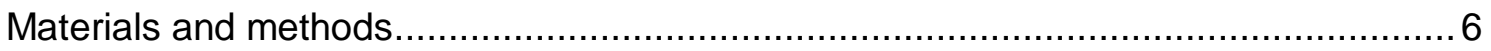

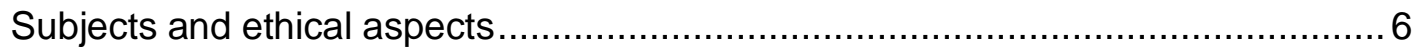

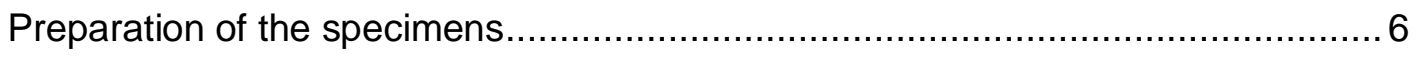

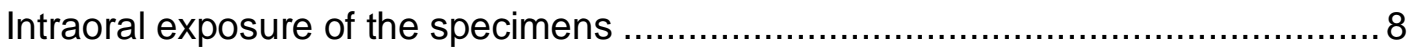

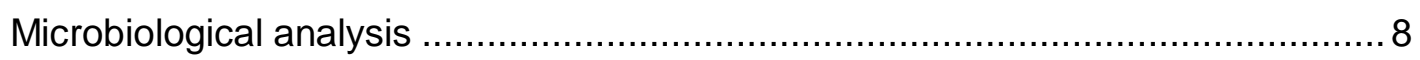

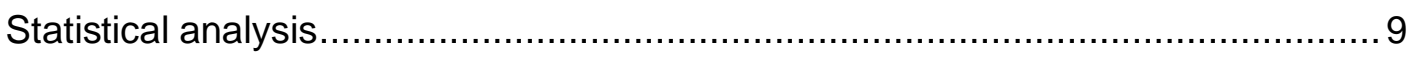

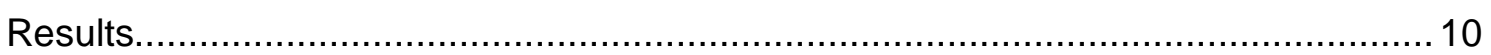

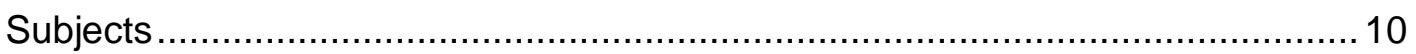

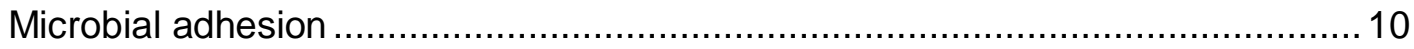

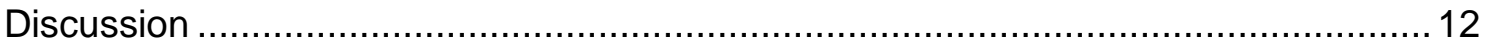

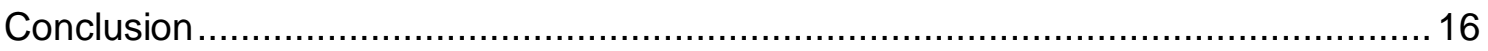

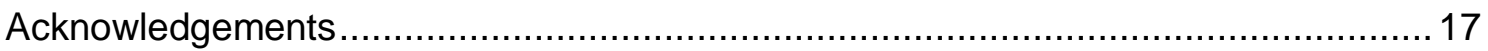

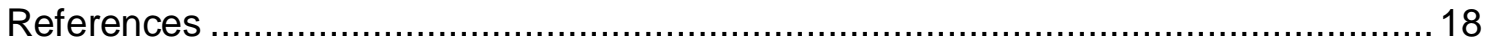

Anexos

Declaração de autoria do trabalho apresentado

Parecer do Orientador para entrega definitiva do trabalho apresentado

Parecer da Comissão de Ética

Explicação do estudo

Declaração de consentimento informado 


\section{Abstract}

Objectives: The aim of this study was to evaluate, in situ, the initial adhesion of microorganisms to a hard acrylic resin used in removable dental prostheses, ProBase $\mathrm{Hot}^{\circledR}$, and to an acrylic-based soft liner, Vertex Soft ${ }^{\circledR}$.

Methods: Equal sized discs of ProBase $\mathrm{Hot}^{\circledR}$ and Vertex Soft ${ }^{\circledR}$ were prepared and polished according to the procedures for clinical use. Two discs of each material were mounted in individual oral splints and exposed during $4 \mathrm{~h}$ to the oral cavity of 15 participants. After this period, the microbial adhesion to both materials' surface was measured by pour plate technique using rich and selective growth media. Statistical analysis was performed using Student's t-test.

Results: Statistically significant differences $(p<0.05)$ were found between the two materials regarding the adhesion of total aerobes, total anaerobes, total streptococci and Mutans streptococci, with Vertex Soft ${ }^{\circledR}$ presenting higher microbial adhesion in comparison to ProBase $\mathrm{Hot}^{\circledR}$

Significance: The Vertex Soft $^{\circledR}$ liner has been found to be more susceptible to microbial adhesion than the acrylic resin base material, ProBase $\mathrm{Hot}^{\circledR}$. The application of Vertex Soft ${ }^{\circledR}$ liner to a hard denture base may lead to a greater risk of oral and systemic infections for patients, highlighting a greater need for plaque control, especially on more susceptible individuals.

Keywords: microbial adhesion, biofilm, in situ, removable dental prosthesis, polymethylmethacrylate, soft liner. 


\section{Resumo}

Objetivos: Avaliação in situ da adesão microbiana à resina acrílica ProBase $\operatorname{Hot}^{\circledR}$, usada na confeção de próteses removíveis, e à resina flexível Vertex $\operatorname{Soft}^{\circledR}$, usada para o rebasamento de próteses removíveis.

Metodologia: Foram preparados discos de resina rígida e de resina flexível de igual tamanho, segundo os procedimentos para uso clínico. Fixaram-se dois discos de cada material em dispositivos intra-orais individuais que foram expostos durante $4 \mathrm{~h}$ à cavidade oral de 15 participantes. Após o período de exposição foi determinada a adesão microbiana a ambos os materiais através do método da contagem em placa, usando meios de cultura ricos e diferenciais. O teste $t$ de Student foi utilizado para a análise estatística.

Resultados: Foram encontradas diferenças estatisticamente significativas $(p<0.05)$ entre os dois materiais relativamente à adesão de aeróbios totais, anaeróbios totais, Streptococcus totais e Streptococcus do grupo Mutans. Em comparação com a resina ProBase $\mathrm{Hot}^{\circledR}$, a resina Vertex Soft ${ }^{\circledR}$ apresentou maior adesão microbiana.

Significância: A resina de rebasamento Vertex $\operatorname{Soft}^{\circledR}$ mostrou-se mais suscetível à adesão microbiana do que a resina acrílica ProBase $\mathrm{Hot}^{\circledR}$. O rebasamento de uma prótese removível com Vertex Soft ${ }^{\circledR}$ poderá condicionar um risco acrescido de infeções orais e sistémicas para os pacientes, realçando-se uma maior necessidade de controlo do biofilme oral, especialmente em indivíduos mais suscetíveis.

Palavras-chave: adesão microbiana, biofilme, in situ, prótese dentária removível, polimetilmetacrilato, rebasamento. 


\section{Introduction}

The conventional heat-polymerized polymethylmethacrylate (PMMA) resins have been widely used on the bases of total and partial removable prostheses [1-5] due to their acceptable esthetics, good thermal conductivity, low permeability to oral fluids, color stability and facility of processing, handling and repair [1-6].

The health of the supporting tissues may be adversely affected by pressure of the prosthesis during use [7] and denture wearers sometimes cannot tolerate a conventional hard denture base [3,7-9]. In such cases, the clinician may recommend soft liners [3,7-10] to provide comfort to the patient [11-14] and reduce pain [11,13,14]. These are compliant, viscoelastic materials used for relining all or part of the fit surface of a removable prosthesis, with the purpose of reducing the impact forces during function by uniform stress distribution, while acting as shock absorbers [11,12,14-21].

Acrylic-based soft liners are composed of polymers (PMMA or polyethylmethacrylate) associated with an acrylic monomer and plasticizers $[12,15,22]$ responsible for preserving the material softness [15]. Their most favorable properties are long-term resiliency and good adhesion to the denture base material [16]. However, these materials may present several problems associated with their use, such as water absorption, permanent deformation [17,23], loss of softness [3,17,23], surface deterioration [17], poor tear strength, color changes [3] and their response to microorganisms, where they have been found to be prone to microbial adhesion $[3,7,11,17,18,20,23-25]$.

In the oral cavity, most colonizing and infecting microorganisms are found as complex microbial communities encapsulated within an extracellular matrix attached to a surface - the biofilms [26-32]. The biofilm is an organized structure, variable in time and space, that comprises synergic interactions between various species of microorganisms, while it modulates their adhesion and metabolic properties [19,26,28,33,34]. Biofilm formation and adhesion depend on the interaction of several factors including surface characteristics [19,35-37] (roughness $[6,18,19,37-42]$ surface free energy [19,37,38,41], hidrophobicity $[19,38,41]$ and porosity [36]), type of microorganisms and saliva properties [19,36,43]. 
It is known that the microbial biofilm forms on the surfaces of a removable prosthesis as it does on the oral structures $[1,19,26,34-36,38,40,44]$. After the insertion of a prosthesis, its surfaces are readily colonized by various microorganisms and a disperse population can be observed after only two hours [26]. Substantial contamination has been reported in vitro after 8 hours of contact between the denture material and microorganisms [44]. These facts may suggest that dentures can play a role as reservoirs for recurring oral infections $[19,44]$. Moreover, continuous swallowing and aspiration of microorganisms from denture plaque may expose more susceptible patients to systemic pathologies $[8,9,18,38,45,46]$ such as gastrointestinal $[33,47]$ and pulmonary infections [33,45-48] and bacterial endocarditis [49-51]. Hence, the microbial adhesion to both denture base materials and soft liners is of clinical importance [18].

Several studies evaluated the adhesion of Candida albicans to soft liners [7,9,20,52-54]. However, adhesion of other microorganisms, such as streptococci, may also be relevant to evaluate as they are early colonizers and represent a major component of oral biofilm $[18,32,55]$.

The formation of the salivary pellicle that coats and modifies the properties of the exposed surfaces on the oral cavity $[19,26,41,43]$ is an important factor for the microbial colonization during the formation of the dental plaque biofilm [56], since it influences and mediates the binding of microorganisms $[19,26,35,43]$. Microbial adhesion should be evaluated in conditions as close as possible to the in vivo situation [19,56], since in vitro studies present difficulties in reproducing the formation of the salivary pellicle $[43,56]$ and can lead to an oversimplification of the real conditions in the oral cavity [56], originating erroneous conclusions. With respect to the aforementioned materials, no in situ studies assessing the susceptibility to microbial adhesion were available; therefore, an in situ approach was applied in the present study. 
In situ evaluation of the microbial adhesion on a hard acrylic resin and on a soft liner used in removable prostheses

Given the above stated, the aim of the present study was to evaluate, in situ, the initial adhesion of total aerobes, total anaerobes, total streptococci and Mutans streptococci to a hard acrylic resin and to an acrylic-based soft liner used in removable dental prostheses.

This study tested the null hypothesis that there are no differences between the materials studied regarding oral microorganisms adherence susceptibility. 


\section{Materials and methods}

\section{Subjects and ethical aspects}

Seventeen healthy students from the Faculty of Dental Medicine of the University of Porto (FMDUP) were invited to participate in this study. Inclusion criteria were absence of active caries, periodontal pathology or any systemic or salivary gland disease that could affect salivation. Visual oral examination was performed in every subject, and Knutson's index was used to access the presence of caries. Fifteen students (five males and ten females) between 22 and 26 years old fulfilled these requirements and were selected to participate in this study. All subjects had high oral hygiene standards and none of them smoked.

The study design was reviewed and approved by the Ethics Committee of FMDUP and free and informed written consent was obtained from all participants, according to the Helsinki Declaration.

\section{Preparation of the specimens}

The heat-polymerized PMMA resin ProBase Hot $^{\circledR}$ (Ivoclar Vivadent, Schaan, Principality of Liechtenstein, liquid Lot nr. G11982, powder Lot nr. K05691), widely used in removable dental prostheses, and a heat-cured acrylic-based soft liner resin, Vertex Soft ${ }^{\circledR}$ (Vertex-Dental, Zeist, The Netherlands, liquid Lot nr. XW182L03, powder Lot nr. XW261P03) were used in this study.

Alginate impressions were taken from the upper jaw of all participants, using Orthoprint ${ }^{\circledR}$ alginate (Zhermack, Badia Polesine, Italy). From the respective casts, individual splint-like oral appliances ranging from first premolar to second molar were vacuum-formed from thermoplastic clear foils (060 Clear, Dentaflux, Madrid, Spain), $125 \mathrm{~mm}$ in diameter and $1.5 \mathrm{~mm}$ thick, as previously described by Claro-Pereira et al. (2011) [57], Sousa et al. (2009) [58] and Tenuta et al (2003) [59]. 
Sixty disc-shaped specimens (9 $\mathrm{mm}$ in diameter and $2 \mathrm{~mm}$ in height) were made, thirty from each material. The discs were prepared according to the manufacturers' instructions, using modeling wax (Kemdent, Purton, United Kingdom) circular patterns with calibrated size so that all specimens had equal surface area (Fig. 1). Each disc was polished according to the standard procedures for clinical use and in order to achieve a similar degree of surface roughness in all specimens of the same material. ProBase $\mathrm{Hot}^{\circledR}$ discs were polished using sandpaper and a polishing rubber, followed by the use of pomice paste (Steribim-Super ${ }^{\circledR}$, BEGO, Bremen, Germany) and a polishing paste (244-BLUE Universal High Shine, KENDA, Vaduz, Principality of Liechtenstein) in a EWL polishing machine (KaVo, Biberach, Germany). The Vertex Soft ${ }^{\circledR}$ discs were polished with Molloplast ${ }^{\circledR}$ Pre-Polisher (DETAX, Ettlingen, Germany).

After the preparation of the discs they were disinfected by ultrasonication for $15 \mathrm{~min}$ in $70 \%$ ethanol and washed twice in sterile distilled water. Two discs from each material were fixed to the palatal surfaces of each oral appliance, so that the ProBase $\mathrm{Hot}^{\circledR}$ discs were located on the right side and the Vertex Soft ${ }^{\circledR}$ discs on the left side (Fig. 2). The oral appliances and discs were stored in aseptic environment before exposure to the oral cavity.

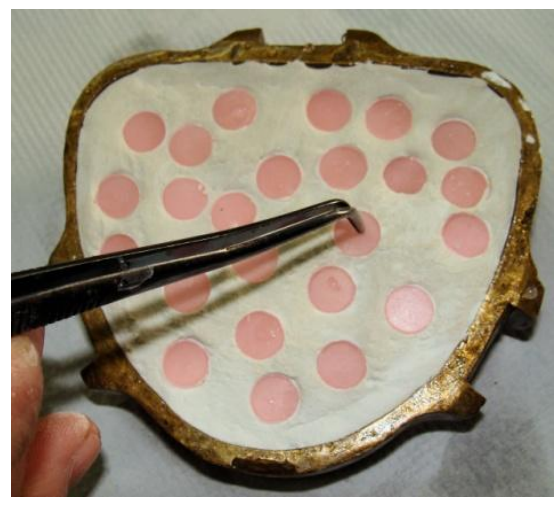

Fig. 1 - Modeling wax calibrated circular patterns used for the fabrication of the samples by compression molding technique. 


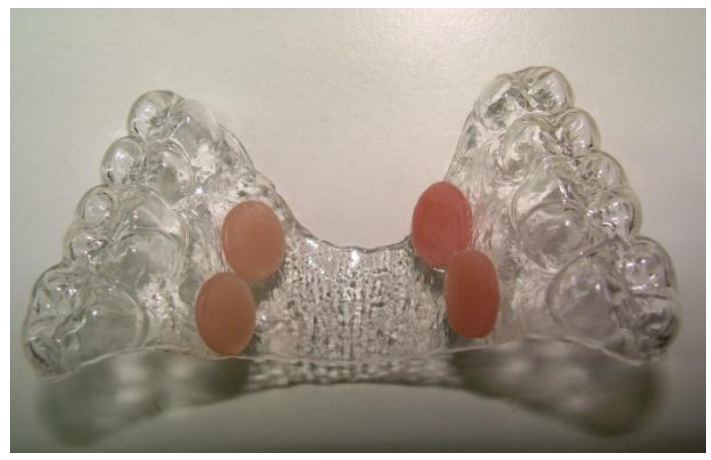

Fig. 2 - Individual oral appliance with mounted sample discs of the two materials.

\section{Intraoral exposure of the specimens}

On the day of the experiment, the participants were instructed not to brush their teeth or use anti-microbial mouth rinses. One hour after breakfast, the subjects were asked to use their individual oral splints with the fixed disc-shaped specimens for a period of $4 \mathrm{~h}$, in order to promote the adhesion of microorganisms to the surface of the specimens (initial biofilm formation). All the experiments occurred between 9.00 a.m. and 1.00 p.m. to ensure standardized procedures. During these $4 \mathrm{~h}$, the participants were instructed not to eat, drink or smoke. At the end of this period, the splints were removed from the subjects' mouth carefully, without touching the discs. All the discs were rinsed equally with sterile isotonic solution $(\mathrm{NaCl}$ $0.9 \%)$, in order to eliminate planktonic and loosely attached cells.

\section{Microbiological analysis}

To determine the number of adhering microorganisms, the sample discs were detached from the splints and placed in sterile tubes containing $0.5 \mathrm{~mL}$ of $0.9 \% \mathrm{NaCl}$ sterile solution and sterile glass beads. The tubes were then vortexed for 3 s and sonicated for $3 \mathrm{~s}$ in an ice bath to promote desorption of the microorganisms from the specimens. This procedure was repeated three more times. Afterwards, the suspensions were serially diluted in $0.9 \% \mathrm{NaCl}$ solution in decimal series until $10^{-3}$. The resulting samples were immediately plated in triplicate in the 
following culture mediums: Brain Heart Infusion agar to determine the total number of aerobic microorganisms, Blood agar to evaluate the total number of anaerobic microorganisms, Mitis salivarius agar containing $1 \%$ potassium tellurite to determine total streptococci and Mitis salivarius agar containing 0.2 units of bacitracin/mL with $20 \%$ sucrose to determine Mutans streptococci. Brain Heart Infusion agar plates were incubated aerobically for seven days at $37^{\circ} \mathrm{C}$. Blood agar, Mitis salivarius agar and Mitis salivarius agar with bacitracin plates were incubated anaerobically for seven days at $37^{\circ} \mathrm{C}$.

The numbers of colonies were counted and the results expressed in colony forming units per square millimeter (CFU/mm²) and converted to $\log _{10}$ (Fig. 3).

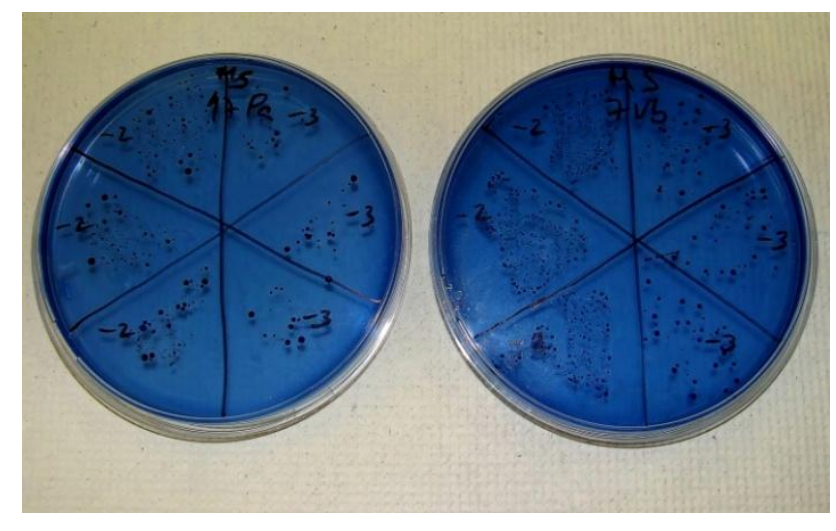

Fig. 3 - Mitis salivarius agar plates with plated ProBase $\mathrm{Hot}^{\circledR}$ dilution samples (on the left) and Vertex Soft ${ }^{\circledR}$ dilution samples (on the right) after incubation.

\section{Statistical analysis}

The results are mean \pm standard error $(\mathrm{SE})$ of values for the indicated number of determinations. Statistical analysis used Student's t-test to detect statistically significant differences between mean values of microbial adhesion between groups. A $p<0.05$ was assumed to denote a significant difference. Statistical analysis was performed using Microsoft Excel 2010 (Redmond, WA, USA). 


\section{Results}

\section{Subjects}

The mean age of the participants was $23.1 \pm 0.3$ years. The Knutson's index value for each participant was 0 , as none of them had visible caries. The number of daily brushings of the subjects varied between 2 and 3 , with a median value of 2 .

\section{Microbial adhesion}

Table 1 shows the mean values of CFU per square millimeter and Fig. 4 shows $\log _{10}$ CFU per square millimeter for each material regarding total aerobic microorganisms, total anaerobic microorganisms, total streptococci and Mutans streptococci.

Table 1 - Microbial adhesion expressed in colony forming units (CFU) per square millimeter for ProBase $\mathrm{Hot}^{\circledR}$ and Vertex Soft ${ }^{\circledR}$ resins.

\begin{tabular}{llcc}
\hline & ProBase Hot $^{\circledR}$ & Vertex Soft $^{\circledR}$ & P \\
\hline Total aerobes & $6.71 \times 10^{3} \pm 8.03 \times 10^{2}$ & $1.45 \times 10^{4} \pm 1.98 \times 10^{3}$ & 0.0006 \\
Total anaerobes & $6.76 \times 10^{3} \pm 1.03 \times 10^{3}$ & $1.33 \times 10^{4} \pm 1.77 \times 10^{3}$ & 0.0023 \\
Streptococci & $7.10 \times 10^{3} \pm 1.35 \times 10^{3}$ & $1.56 \times 10^{4} \pm 1.65 \times 10^{3}$ & 0.0002 \\
Mutans streptococci & $1.39 \times 10^{1} \pm 2.41 \times 10^{0}$ & $2.90 \times 10^{1} \pm 5.05 \times 10^{0}$ & 0.0089 \\
\hline
\end{tabular}

Values are means \pm SE for $n=30$ for each group. 


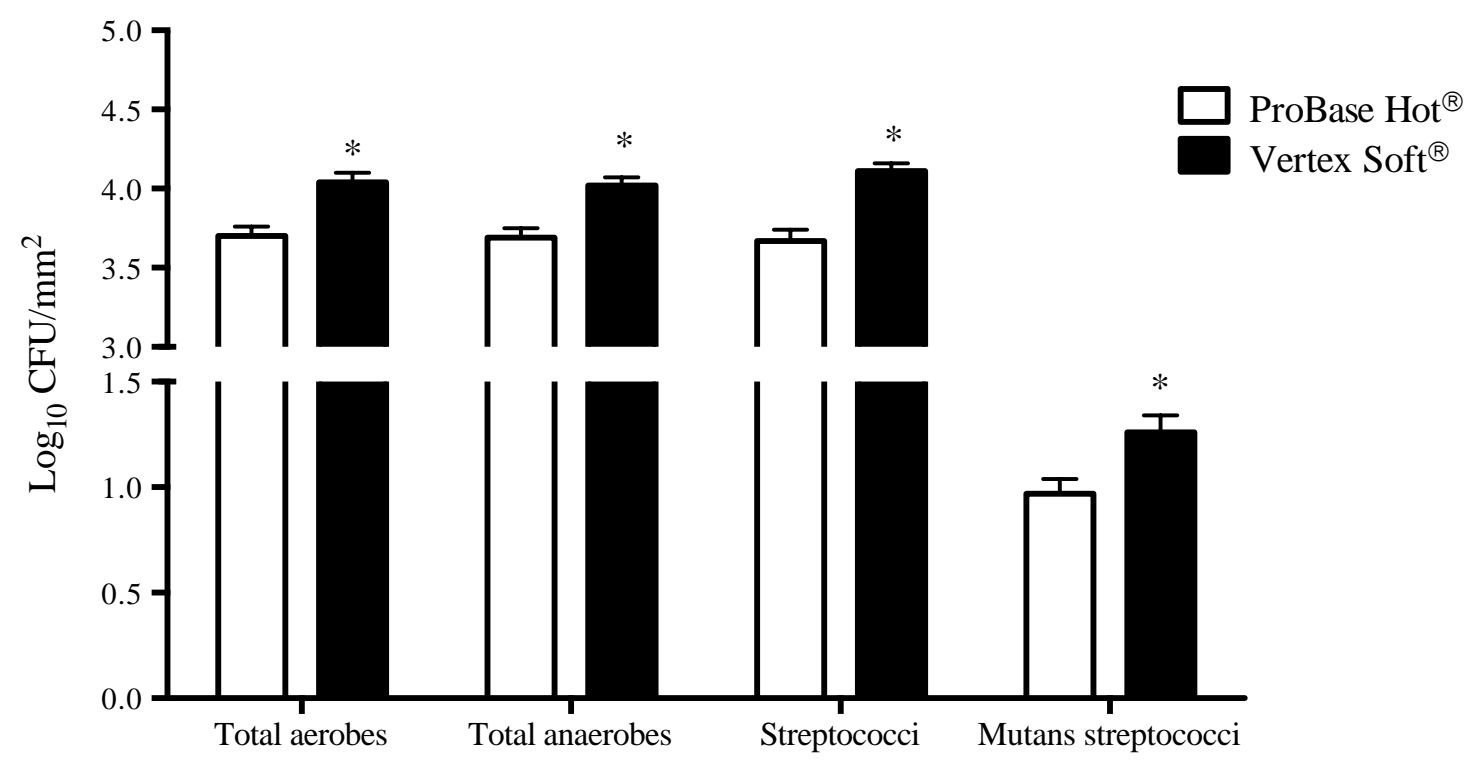

Fig. 4 - Microbial adhesion expressed in $\log _{10}$ of colony forming units (CFU) per square millimeter for ProBase $\mathrm{Hot}^{\circledR}$ and Vertex $\operatorname{Soft}^{\circledR}$ resins. Bars represent means and error bars represent SE. *Statistically different from ProBase $\mathrm{Hot}^{\circledR}$.

Statistically significant differences $(p<0.05)$ were found between the two materials regarding the adhesion of total aerobes, total anaerobes, total streptococci and Mutans streptococci. The results show that Vertex Soft $^{\circledR}$ was more susceptible to microbial adhesion than ProBase $\mathrm{Hot}^{\circledR}$ irrespective of the type of microorganisms evaluated. 


\section{Discussion}

In this study we compared in situ the microbial adhesion to a heat-polymerized rigid PMMA acrylic resin, ProBase $\mathrm{Hot}^{\circledR}$, and to a heat-polymerized acrylic-based soft lining material, Vertex Soft ${ }^{\circledR}$. Statistically significant differences were found between the two materials regarding the adhesion of total aerobes, total anaerobes, total streptococci and Mutans streptococci. Therefore, the null hypothesis, that stated that there are no differences in oral microorganisms adherence susceptibility between the two materials tested, was rejected. The results showed that, under equal conditions, a higher microbial adhesion on Vertex Soft ${ }^{\circledR}$ specimens was observed.

A soft denture liner can be applied to the fitting surface of a denture to reduce discomfort and pain for the patient. One of the basic problems with using soft liners is the colonization by microorganisms, which is fostered by the high humidity and elevated temperature found under dentures and by the material's structure [24].

Microbial adhesion to the surface of a removable dental prosthesis may be the first step that can lead to the development of an infectious process [18]. Also of clinical relevance is the fact that biofilms are less susceptible to host immunity $[28,37]$ and antimicrobial agents [28,31,37], and can display enhanced pathogenicity [31]. Additionally, microbial adhesion can lead to the bio-deterioration of the materials, which may require the removal or remaking of the prosthesis and/or the lining material [8]. Therefore, an optimized denture base material should exhibit minimal susceptibility to the adhesion of microorganisms while maintaining the desired physical properties [5].

In the present and previous studies [57,60-62], a time period of $4 \mathrm{~h}$ was chosen because initial bacterial adhesion, which is determinant for the establishment and maturation of the biofilm [61], occurs within $4 \mathrm{~h}$ of the salivary pellicle formation [28]. The resin discs sampling technique has shown to be a method that allows studying the formation of denture biofilm in its natural environment [26].

In this study, a significant count of streptococci was obtained for both materials. This result shows that the early primary colonizers were essentially streptococci, which were 
probably counted in both aerobic and anaerobically incubated cultures, since they are facultative anaerobes. These findings are in accordance with previous studies about initial bacterial colonization of oral surfaces $[28,56,60,63,64]$.

Streptococci belonging to the Mutans group (comprising the species Streptococcus mutans and Streptococcus sobrinus) were found in very low quantities. This result may be related to the low concentration of Mutans streptococci present in the oral cavity of the participants. While they are part of the normal microbiota of the mouth, these microorganisms have been consistently associated with dental caries [1,31,35,46,49,51,64-69] and it is noteworthy that all participants were caries-free. Also, within Streptococcus spp., Mutans streptococci are later colonizers [70], although they may take part on the initial colonization $[29,51,70]$.

The adhesion of early colonizers is determinant for the subsequent adhesion of other species to the denture surface [63] because late colonizers interact and co-aggregate with them $[17,28,32,37,63,65]$ and thus the subsequent maturation of the biofilm proceeds [37]. Some of the most pathogenic microorganisms of the oral cavity are known to be late colonizers $[37,67,71]$.

The roughness of intraoral hard surfaces is of clinical concern since it favors microbial adhesion and retention [6,18-20,37-42,52] and, consequently, oral infections [17,52]. That occurs because the irregularities of the surfaces allow the attached microorganisms to survive longer, since they are protected from the removal forces originating from oral hygiene habits $[19,37,40]$. In addition, the superficial roughness increases the available area for the adhesion of microorganisms $[7,8,17,37]$.

The results obtained in this study are possibly related to the surface roughness of the materials, since soft liners are known to have a superior surface roughness to that of acrylic resins [19] and so, when exposed to the oral environment, they are potentially more susceptible to microbial adhesion and biofilm formation [19]. The higher roughness of acrylic-based soft liners might be associated with the chemical composition of these materials [15]. As for conventional acrylic resin, surface roughness is related to the presence of porosities within the material [15]. 
The different polishing techniques used on the two materials might have influenced their surface roughness $[6,19,40]$ and microbial adhesion. In the fabrication of the sample discs, the finishing and polishing procedures were conducted as if preparing a denture base/reline for clinical use and a distinct standard polishing procedure is usually applied for each material. This warrants further investigation to examine the differences between the grits and polishing methods used in polishing the two materials.

This study can also give rise to questions about the differences in the physical and chemical properties of the surfaces of each of the resins, since they play a role in the adhesion of microorganims to a denture surface $[8,17,39]$. However, due to the proprietary nature of the components of these materials, the true differences between them may never be known to their fullest extent.

Idiosyncratic factors, such as diet, salivary composition and secretion rate as well as the antibodies titer also influence the microbial adhesion [19,31,43]. Hence, the inter-individual variability in the microbial counts is very important to consider. In order to minimize this, the selected participants of this study presented similar characteristics and all subjects carried both materials simultaneously.

According to the results, a significant quantity of microorganisms was present on the surfaces of both the denture base resin and the soft liner. As these microorganisms may ultimately be responsible for a number of diseases, dentists must remain aware that these materials, particularly the soft liner, can act as microbial reservoirs [19,44] and their use increases the possibility of infection occurrence $[18,44]$, especially on more susceptible patients.

Biofilm removal by means of adequate hygiene is mandatory for the maintenance of the oral health of all denture wearers [72]. Regarding the materials used for the construction of denture bases, soft liners would serve as different surfaces for biofilm formation that may alter the susceptibility of a removable prosthesis to microbial adhesion and colonization and require specific strategies for adequate cleaning $[10,36]$. Therefore, an extended control of denture plaque and biofilm is important for the clinical use of these materials and for maintaining a healthy oral mucosa $[7,10,15,23,40,72]$, minimizing the risk of oral and systemic infections. Dentists should, thus, instruct their patients regarding extra care in using a relined removable 
prosthesis and profess frequent clinical evaluations and eventual periodic replacement of the lining material, when required [23].

Additional methods may be used to reduce the microbial adhesion to soft denture liners and extend their longevity, such as a more complete and definitive polishing protocol and the use of surface sealers. According to Nishioka et al. (2006) [73], surface roughness decreases significantly as the polishing process progresses. However, one must consider the limitations inherent to the material's properties. Mainieri et al. (2011) [36] and Olan-Rodriguez et al. (2000) [54] have reported that sealed soft liners showed less microorganism growth and biofilm formation in comparison to unsealed ones.

Some of the limitations of this study include material variables, because only one brand of each type of resin was tested, and polishing techniques variables, because different polishing techniques were used for each material. Moreover, microbiological culture methods evaluate a specific group of microorganisms or a particular species. Many oral microorganisms are uncultivable, and so, not detected by this methodology.

Additional studies using detection methods like confocal laser scanning microscopy (CLSM), fluorescent in situ hybridization (FISH) or checkerboard DNA-DNA hybridization would provide a more specific identification and quantification of the species of microorganisms adhered to these materials. Further investigation of the materials' surface characteristics, like roughness, hidrophobicity and surface free energy, would allow for the association of such characteristics to susceptibility to microbial adhesion. 


\section{Conclusion}

Vertex Soft ${ }^{\circledR}$, a heat-polymerized acrylic-based soft denture liner, exhibited higher microbial adhesion in comparison to ProBase $\mathrm{Hot}^{\circledR}$, a heat-polymerized acrylic resin widely used in denture bases, regarding total aerobes, total anaerobes, total streptococci and Mutans streptococci. The application of Vertex Soft ${ }^{\circledR}$ liner to a hard denture base may lead to a greater risk of oral and systemic infections for patients, highlighting a greater need for plaque control, especially on more susceptible individuals. 


\section{Acknowledgements}

This study was financed by The Faculty of Dental Medicine of the University of Porto. The authors wish to express their gratitude to Mr. Carlos Costa for his kind help in the preparation of the oral splints and Mr. Américo Ribeiro for preparing the sample discs. They also wish to thank all the participants that took part in this study. 


\section{References}

1. Dhir G, Berzins DW, Dhuru VB, Periathamby AR and Dentino A. Physical properties of denture base resins potentially resistant to Candida adhesion. J Prosthodont, 2007; 16(6):465-72.

2. Goiato MC, Santos DM, Haddad MF and Pesqueira AA. Effect of accelerated aging on the microhardness and color stability of flexible resins for dentures. Braz Oral Res, 2010; 24(1):114-9.

3. Imirzalioglu P, Karacaer O, Yilmaz B and Ozmen Msc I. Color stability of denture acrylic resins and a soft lining material against tea, coffee, and nicotine. J Prosthodont, 2010; 19(2):118-24.

4. Jain T, Yadav NS, Pandita A, Feroz SM, Kartika UK and Singh PP. A comparative evaluation of flexural strength of commercially available acrylic and modified polymethylmethacrylate: an in vitro study. J Contemp Dent Pract, 2013; 14(1):80-3.

5. Park SE, Chao M and Raj PA. Mechanical properties of surface-charged poly(methyl methacrylate) as denture resins. Int J Dent, 2009; 2009:841431.

6. Abuzar MA, Bellur S, Duong N, Kim BB, Lu P, Palfreyman N, et al. Evaluating surface roughness of a polyamide denture base material in comparison with poly (methyl methacrylate). J Oral Sci, 2010; 52(4):577-81.

7. Boscato N, Radavelli A, Faccio D and Loguercio AD. Biofilm formation of Candida albicans on the surface of a soft denture-lining material. Gerodontology, 2009; 26(3):210-3.

8. Mutluay MM, Oguz S, Orstavik D, Floystrand F, Dogan A, Soderling E, et al. Experiments on in vivo biofilm formation and in vitro adhesion of Candida species on polysiloxane liners. Gerodontology, 2010; 27(4):283-91.

9. Nikawa H, Jin C, Makihira S, Egusa H, Hamada T and Kumagai H. Biofilm formation of Candida albicans on the surfaces of deteriorated soft denture lining materials caused by denture cleansers in vitro. J Oral Rehabil, 2003; 30(3):243-50.

10. Jin C, Nikawa $\mathrm{H}$, Makihira $\mathrm{S}$, Hamada $\mathrm{T}$, Furukawa $\mathrm{M}$ and Murata $\mathrm{H}$. Changes in surface roughness and colour stability of soft denture lining materials caused by denture cleansers. J Oral Rehabil, 2003; 30(2):125-30.

11. Chladek G, Mertas A, Barszczewska-Rybarek I, Nalewajek T, Zmudzki J, Krol W, et al. Antifungal activity of denture soft lining material modified by silver nanoparticles-a pilot study. Int J Mol Sci, 2011; 12(7):4735-44.

12. Ergun $\mathrm{G}$ and Nagas IC. Color stability of silicone or acrylic denture liners: an in vitro investigation. Eur J Dent, 2007; 1(3):144-51. 
13. Fuji $\mathrm{K}$, Arikawa $\mathrm{H}$, Kanie $\mathrm{T}$, Shinohara $\mathrm{N}$ and Inoue $\mathrm{K}$. Effect of photo-irradiation on hardness of soft lining materials for denture base. J Oral Rehabil, 2002; 29(8):744-8.

14. Mutluay MM and Ruyter IE. Evaluation of bond strength of soft relining materials to denture base polymers. Dent Mater, 2007; 23(11):1373-81.

15. Dayrell A, Takahashi J, Valverde G, Consani R, Ambrosano G and Mesquita M. Effect of sealer coating on mechanical and physical properties of permanent soft lining materials. Gerodontology, 2012; 29(2):e401-7.

16. Mahajan $\mathrm{N}$ and Datta K. Comparison of bond strength of auto polymerizing, heat cure soft denture liners with denture base resin - An In Vitro study. J Indian Prosthodont Soc, 2010; 10(1):31-5.

17. Pavan S, Arioli Filho JN, Dos Santos PH, Nogueira SS and Batista AU. Effect of disinfection treatments on the hardness of soft denture liner materials. J Prosthodont, 2007; 16(2):101-6.

18. Pavan S, dos Santos PH, Filho JN and Spolidorio DM. Colonisation of soft lining materials by micro-organisms. Gerodontology, 2010; 27(3):211-6.

19. Pereira-Cenci T, Del Bel Cury AA, Crielaard W and Ten Cate JM. Development of Candida-associated denture stomatitis: new insights. J Appl Oral Sci, 2008; 16(2):8694.

20. Vural C, Ozdemir G, Kurtulmus H, Kumbuloglu O and Ozcan M. Comparative effects of two different artificial body fluids on Candida albicans adhesion to soft lining materials. Dent Mater J, 2010; 29(2):206-12.

21. Sadr K, Alipour J and Heidary F. Finite Element Analysis of Soft-lined Mandibular Complete Denture and its Supporting Structures. J Dent Res Dent Clin Dent Prospects, 2012; 6(2):37-41.

22. Goiato MC, Zuccolotti BC, Moreno A, dos Santos DM, Pesqueira AA and Dekon SF. Colour change of soft denture liners after storage in coffee and coke. Gerodontology, $2011 ; 28(2): 140-5$.

23. Pisani MX, Silva-Lovato CH, Malheiros-Segundo Ade L, Macedo AP and Paranhos HF. Bond strength and degree of infiltration between acrylic resin denture liner after immersion in effervescent denture cleanser. J Prosthodont, 2009; 18(2):123-9.

24. Chladek G, Kasperski J, Barszczewska-Rybarek I and Zmudzki J. Sorption, solubility, bond strength and hardness of denture soft lining incorporated with silver nanoparticles. Int J Mol Sci, 2012; 14(1):563-74.

25. Faccio DR, Pereira-Cenci T, Cenci MS, Demarco FF, Moraes RR and Boscato N. In vivo biofilm formation on a soft denture liner in elderly patients with controlled diabetes. Gerodontology, 2012; 29(2):e143-6.

26. Avon SL, Goulet JP and Deslauriers N. Removable acrylic resin disk as a sampling system for the study of denture biofilms in vivo. J Prosthet Dent, 2007; 97(1):32-8. 
27. Bowen $\mathrm{WH}$ and $\mathrm{Koo} \mathrm{H}$. Biology of Streptococcus mutans-derived glucosyltransferases: role in extracellular matrix formation of cariogenic biofilms. Caries Res, 2011; 45(1):6986.

28. Dhir S. Biofilm and dental implant: The microbial link. J Indian Soc Periodontol, 2013; 17(1):5-11.

29. Ma R, Liu J, Jiang YT, Liu Z, Tang ZS, Ye DX, et al. Modeling of diffusion transport through oral biofilms with the inverse problem method. Int J Oral Sci, 2010; 2(4):190-7.

30. Mannaa A, Carlen A, Campus G and Lingstrom P. Supragingival plaque microbial analysis in reflection to caries experience. BMC Oral Health, 2013; 13:5.

31. Marsh PD. Dental plaque as a biofilm and a microbial community - implications for health and disease. BMC Oral Health, 2006; 6 Suppl 1:S14.

32. Zijnge V, van Leeuwen MB, Degener JE, Abbas F, Thurnheer T, Gmur R, et al. Oral biofilm architecture on natural teeth. PLoS One, 2010; 5(2):e9321.

33. Cruz PC, Andrade IM, Peracini A, Souza-Gugelmin MC, Silva-Lovato CH, de Souza RF, et al. The effectiveness of chemical denture cleansers and ultrasonic device in biofilm removal from complete dentures. J Appl Oral Sci, 2011; 19(6):668-73.

34. ten Cate JM. Biofilms, a new approach to the microbiology of dental plaque. Odontology, 2006; 94(1):1-9.

35. Gocke R, Gerath F and von Schwanewede H. Quantitative determination of salivary components in the pellicle on PMMA denture base material. Clin Oral Investig, 2002; 6(4):227-35.

36. Mainieri VC, Beck J, Oshima HM, Hirakata LM and Shinkai RS. Surface changes in denture soft liners with and without sealer coating following abrasion with mechanical brushing. Gerodontology, 2011; 28(2):146-51.

37. Teughels W, Van Assche N, Sliepen I and Quirynen M. Effect of material characteristics and/or surface topography on biofilm development. Clin Oral Implants Res, 2006; 17 Suppl 2:68-81.

38. Bal BT, Yavuzyilmaz $\mathrm{H}$ and Yucel M. A pilot study to evaluate the adhesion of oral microorganisms to temporary soft lining materials. J Oral Sci, 2008; 50(1):1-8.

39. Berger JC, Driscoll CF, Romberg E, Luo Q and Thompson G. Surface roughness of denture base acrylic resins after processing and after polishing. J Prosthodont, 2006; 15(3):180-6.

40. Oliveira LV, Mesquita MF, Henriques GE, Consani RL and Fragoso WS. Effect of polishing technique and brushing on surface roughness of acrylic resins. J Prosthodont, 2008; 17(4):308-11. 
41. Radford DR, Challacombe SJ and Walter JD. Denture plaque and adherence of Candida albicans to denture-base materials in vivo and in vitro. Crit Rev Oral Biol Med, 1999; 10(1):99-116.

42. Yamauchi M, Yamamoto $\mathrm{K}$, Wakabayashi $\mathrm{M}$ and Kawano J. In vitro adherence of microorganisms to denture base resin with different surface texture. Dent Mater J, 1990; 9(1):19-24.

43. Hannig $C$ and Hannig $M$. The oral cavity--a key system to understand substratumdependent bioadhesion on solid surfaces in man. Clin Oral Investig, 2009; 13(2):12339.

44. Glass RT, Bullard JW, Hadley CS, Mix EW and Conrad RS. Partial spectrum of microorganisms found in dentures and possible disease implications. J Am Osteopath Assoc, 2001; 101(2):92-4.

45. Paju S and Scannapieco FA. Oral biofilms, periodontitis, and pulmonary infections. Oral Dis, 2007; 13(6):508-12.

46. Scannapieco FA. Pneumonia in nonambulatory patients. The role of oral bacteria and oral hygiene. J Am Dent Assoc, 2006; 137 Suppl:21S-25S.

47. Srinivasan $M$ and Gulabani M. A microbiological evaluation of the use of denture cleansers in combination with an oral rinse in complete denture patients. Indian J Dent Res, 2010; 21(3):353-6.

48. Aas JA, Paster BJ, Stokes LN, Olsen I and Dewhirst FE. Defining the normal bacterial flora of the oral cavity. J Clin Microbiol, 2005; 43(11):5721-32.

49. Lemos JA and Burne RA. A model of efficiency: stress tolerance by Streptococcus mutans. Microbiology, 2008; 154(Pt 11):3247-55.

50. Thurnheer T, Gmur R, Giertsen E and Guggenheim B. Automated fluorescent in situ hybridization for the specific detection and quantification of oral streptococci in dental plaque. J Microbiol Methods, 2001; 44(1):39-47.

51. Wang BY, Deutch A, Hong J and Kuramitsu HK. Proteases of an early colonizer can hinder Streptococcus mutans colonization in vitro. J Dent Res, 2011; 90(4):501-5.

52. Bulad K, Taylor RL, Verran J and McCord JF. Colonization and penetration of denture soft lining materials by Candida albicans. Dent Mater, 2004; 20(2):167-75.

53. Hahnel S, Rosentritt M, Burgers R, Handel G and Lang R. Candida albicans biofilm formation on soft denture liners and efficacy of cleaning protocols. Gerodontology, 2012; 29(2):e383-91.

54. Olan-Rodriguez L, Minah GE and Driscoll CF. Candida albicans colonization of surfacesealed interim soft liners. J Prosthodont, 2000; 9(4):184-8.

55. Monsenego P. Presence of microorganisms on the fitting denture complete surface: study 'in vivo'. J Oral Rehabil, 2000; 27(8):708-13. 
56. Al-Ahmad A, Wunder A, Auschill TM, Follo M, Braun G, Hellwig E, et al. The in vivo dynamics of Streptococcus spp., Actinomyces naeslundii, Fusobacterium nucleatum and Veillonella spp. in dental plaque biofilm as analysed by five-colour multiplex fluorescence in situ hybridization. J Med Microbiol, 2007; 56(Pt 5):681-7.

57. Claro-Pereira D, Sampaio-Maia B, Ferreira C, Rodrigues A, Melo LF and Vasconcelos MR. In situ evaluation of a new silorane-based composite resin's bioadhesion properties. Dent Mater, 2011; 27(12):1238-45.

58. Sousa RP, Zanin IC, Lima JP, Vasconcelos SM, Melo MA, Beltrao HC, et al. In situ effects of restorative materials on dental biofilm and enamel demineralisation. J Dent, 2009; 37(1):44-51.

59. Tenuta LM, Lima JE, Cardoso CL, Tabchoury CP and Cury JA. Effect of plaque accumulation and salivary factors on enamel demineralization and plaque composition in situ. Pesqui Odontol Bras, 2003; 17(4):326-31.

60. Diaz PI, Chalmers NI, Rickard AH, Kong C, Milburn CL, Palmer RJ, Jr., et al. Molecular characterization of subject-specific oral microflora during initial colonization of enamel. Appl Environ Microbiol, 2006; 72(4):2837-48.

61. Montanaro L, Campoccia D, Rizzi S, Donati ME, Breschi L, Prati C, et al. Evaluation of bacterial adhesion of Streptococcus mutans on dental restorative materials. Biomaterials, 2004; 25(18):4457-63.

62. Rosentritt M, Hahnel S, Groger G, Muhlfriedel B, Burgers R and Handel G. Adhesion of Streptococcus mutans to various dental materials in a laminar flow chamber system. $J$ Biomed Mater Res B Appl Biomater, 2008; 86(1):36-44.

63. Kolenbrander PE. Multispecies communities: interspecies interactions influence growth on saliva as sole nutritional source. Int J Oral Sci, 2011; 3(2):49-54.

64. Suzuki N, Yoshida A and Nakano Y. Quantitative analysis of multi-species oral biofilms by TaqMan Real-Time PCR. Clin Med Res, 2005; 3(3):176-85.

65. He XS and Shi WY. Oral microbiology: past, present and future. Int J Oral Sci, 2009; $1(2): 47-58$.

66. Holbrook WP and Magnusdottir MO. Studies on strains of Streptococcus mutans isolated from caries-active and caries-free individuals in Iceland. J Oral Microbiol, 2012; 4.

67. Kuboniwa M, Tribble GD, Hendrickson EL, Amano A, Lamont RJ and Hackett M. Insights into the virulence of oral biofilms: discoveries from proteomics. Expert Rev Proteomics, 2012; 9(3):311-23.

68. Nishikawara F, Katsumura S, Ando A, Tamaki Y, Nakamura Y, Sato K, et al. Correlation of cariogenic bacteria and dental caries in adults. J Oral Sci, 2006; 48(4):245-51. 
69. Renye JA, Jr., Piggot PJ, Daneo-Moore L and Buttaro BA. Persistence of Streptococcus mutans in stationary-phase batch cultures and biofilms. Appl Environ Microbiol, 2004; 70(10):6181-7.

70. van der Mei HC, Rustema-Abbing M, de Vries $\mathrm{J}$ and Busscher HJ. Bond strengthening in oral bacterial adhesion to salivary conditioning films. Appl Environ Microbiol, 2008; 74(17):5511-5.

71. Davey ME. Tracking dynamic interactions during plaque formation. J Bacteriol, 2008; 190(24):7869-70.

72. Andre RF, Andrade IM, Silva-Lovato $\mathrm{CH}$, Paranhos Hde F, Pimenta FC and Ito IY. Prevalence of mutans streptococci isolated from complete dentures and their susceptibility to mouthrinses. Braz Dent J, 2011; 22(1):62-7.

73. Nishioka M, Yamabe $\mathrm{Y}$, Hisatsune $\mathrm{K}$ and Fujii $\mathrm{H}$. Influence of polishing of denture base resin and metal surfaces on wettability with water and saliva. Dent Mater J, 2006; 25(1):161-5. 


\section{Explicação do Estudo}

\section{Tema do trabalho}

"Estudo da adesão microbiana em dois tipos de resinas para próteses removíveis"

\section{Objetivos}

Avaliação in situ da adesão de microrganismos a dois tipos de resina usados atualmente na confeção de próteses removíveis totais e parciais: uma resina de polimetilmetacrilato e uma resina flexível de rebasamento.

\section{Material e métodos}

Será realizado um exame clínico para verificar a ausência de cáries ativas e patologia periodontal em cada participante, sendo depois efetuada uma impressão em alginato do maxilar. Para cada participante será confecionado um dispositivo intra-oral (tipo goteira) no qual serão colocadas amostras das resinas a testar. No dia acordado com os participantes, estes terão de usar o dispositivo intra-oral durante 4 horas em que não podem comer, beber ou fumar.

\section{Resultados/ benefícios esperados}

O estudo da adesão microbiana in situ a uma resina de polimetilmetacrilato e a uma resina flexível de rebasamento permitirá avaliar qual o tipo de resinas que apresenta maior propensão para a adesão microbiana. O conhecimento da suscetibilidade de diferentes tipos de resina usados em próteses removíveis à adesão microbiana pode contribuir para alertar os pacientes e os clínicos para a adopção de cuidados de higiene mais extensos e específicos em próteses rebasadas.

\section{Riscos/desconforto}

Este estudo não acarreta qualquer risco para os particpantes. A realização de impressões em alginato e o uso das goteiras poderá infligir apenas algum desconforto passageiro e a não escovagem dos dentes no dia da experiência não apresenta prejuízos significativos para a higiene oral dos participantes. 


\section{Faculdade de Medicina Dentária da Universidade do Porto}

Mestrado Integrado em Medicina Dentária

Dissertação de Investigação

\section{Caraterísticas éticas}

O presente estudo foi aprovado pela comissão de ética da Faculdade de Medicina Dentária da Universidade do Porto e serão tidas em conta as regras bioéticas aplicadas a este tipo de investigações. O estudo será realizado após o consentimento livre e informado de cada participante. A investigadora prontifica-se a esclarecer qualquer dúvida, referindo o âmbito do trabalho, garantindo a confidencialidade dos dados e o anonimato da pessoa em questão. Esta investigação não tem quaisquer fins financeiros ou económicos, sendo apenas meramente académica. Qualquer participante pode desistir a qualquer momento sem qualquer prejuízo.

de de

Declaro que recebi, li e compreendi a explicação do estudo.

\section{Assinatura do(a) participante:}




\section{DECLARAÇÃO DE CONSENTIMENTO INFORMADO}

\section{Considerando a Declaração de Helsínquia da Associação Médica Mundial}

Título: "Estudo da adesão microbiana em dois tipos de resinas para próteses removíveis"

(nome completo), compreendi a explicação que me foi fornecida, por escrito e verbalmente, acerca da investigação com o título "Estudo da adesão microbiana em dois tipos de resinas para próteses removíveis" conduzida pela investigadora Ana Sofia Monteiro Gomes na Faculdade de Medicina Dentária da Universidade do Porto, para a qual é pedida a minha participação. Foi-me dada oportunidade de fazer as perguntas que julguei necessárias, e para todas obtive resposta satisfatória.

Tomei conhecimento de que, de acordo com as recomendações da Declaração de Helsínquia, a informação que me foi prestada versou os objetivos, os métodos, os benefícios previstos, os riscos potenciais e o eventual desconforto. Além disso, foi-me afirmado que tenho o direito de decidir livremente aceitar ou recusar a todo o tempo a minha participação no estudo. Sei que posso abandonar o estudo e que não terei que suportar qualquer penalização, nem quaisquer despesas pela participação neste estudo.

Foi-me dado todo o tempo de que necessitei para refletir sobre esta proposta de participação.

Nestas circunstâncias, consinto participar neste projeto de investigação, tal como me foi apresentado pela investigadora responsável, sabendo que a confidencialidade dos participantes e dos dados a eles referentes se encontra assegurada.

Mais autorizo que os dados deste estudo sejam utilizados para este e outros trabalhos científicos, desde que irreversivelmente anonimizados.

Data

Assinatura do(a) participante:

Dados de contato:

A Investigadora: Ana Sofia Monteiro Gomes

Telemóvel: 911803282

E-mail: mimd09116@fmd.up.pt

Morada: Rua Dr. Manuel Pereira da Silva, 4200-393 Porto

A orientadora: Maria Helena Guimarães Figueiral da Silva

Telefone: 220901100

E-mail: mhsilva@fmd.up.pt

Morada: Rua Dr. Manuel Pereira da Silva, 4200-393 Porto

A co-orientadora: Maria Benedita Almeida Garrett de Sampaio-Maia Marques

Telefone: 220901100

E-mail: bmaia@fmd.up.pt

Morada: Rua Dr. Manuel Pereira da Silva, 4200-393 Porto 